3 часу заснування Агробіотехнологічного (Агрономічного) факультету. (Біла Церква, 26-27 березня 2020 року). Біла Церква, 2020. С. 3-4

3. Присяжнюк О. І., Сонець Т. Д., Половинчук О. Ю., Коровко I.I. Комплексна оцінка сучасних гібридів цукрових буряків. наукові праці інституту біоенергетичних культур $i$ иукрових буряків. 2016. № 24. C. $18-27$.

4. Методика проведення експертизи сортів рослин групи технічних та кормових на придатність до поширення в Україні / за ред. Ткачик С. О. Вінниця, 2016. 74 с.

5. Державний реєстр сортів рослин, придатних для поширення в Україні на 2021 рік URL: https://agro.me.gov.ua/storage/app/uploads/ public/608/12f/4b5/60812f4b591ea587635116.pdf (дата звернення: 25.06.2021)

DOI https://doi.org/10.30525/978-9934-26-111-4-54

\title{
ХАРАКТЕРИСТИКА СОРТІВ КАРТОПЛІ ЗОНИ ПОЛІССЯ ЗА ПАРАМЕТРАМИ АДАПТИВНОСТІ
}

\author{
Сонець Т. Д.
}

завідувач сектору технічних, кормових та олійних сортів рослин відділу експертизи на придатність до поширення сортів рослин Украӥнський інститут експертизи сортів рослин м. Київ, Україна

В Україні картопля є однією з основних продовольчих культур. Ïї вирощують в усіх грунтово-кліматичних зонах.

Використання сортів 3 високою адаптивною здатністю до певних природно кліматичних та фітосанітарних умов - основна складова отримання стабільно високих урожаїв картоплі.

Суттєвим чинником в адаптивному рослинництві $є$ сорт. Найбільш вагомою властивістю сорту повинна бути його адаптивність, тобто пристосованість до нового середовища. Специфічна адаптивність властивість рослин максимально утилізувати сприятливі умови середовища (сонячну радіацію, довжину дня, вологу та ін.). Поряд 3 специфічною, сортам повинна бути властива і загальна адаптивна здатність - реалізація потенційної продуктивності за щорічної зміни метеорологічних умов. За визначенням Малявко А.А. - першочергове значення має рівень потенційної урожайності, яка $€$ інтегральним 232 
показником цінності будь якого сорту, його стійкості до несприятливих умов середовища, хвороб і шкідників [1].

Враховуючи потенційну генетичну адаптацію сортів картоплі до річних грунтово-кліматичних зон вирощування можна отримати високий рівень продуктивності картоплі. Отже важливою ознакою сортів $\epsilon$ їх адаптивність до критичних фаз періоду вегетації та дії на рослини окремих чинників навколишнього середовища $[2,3,4,5]$.

Дослідження проведені у зоні Полісся України на ділянках 3 найбільш поширеними для даних зон грунтами. Обліки та спостереження здійснювали відповідно до Методичних рекомендацій щодо проведення досліджень з картоплею.

Адаптивну здатність сортів картоплі оцінювали згідно 3 науковометодичними рекомендаціями «Оцінка адаптивної здатності сортів картоплі за зрошення в зоні південного Степу України» [6].

Реакція кожного із сортів визначалась порівнянням його урожайності за конкретний рік до середньосортової урожайності цього ж року. Основним критерієм сорту, який вирізняється високою адаптивністю в певній агрокліматичній зоні $є$ коефіцієнт адаптивності 3 показником 1 і вище.

Використовуючи даний метод сорти, які досліджувались, розташувались стосовно отриманого коефіцієнту адаптивності таким чином: надранні - 'Прада' $(1,24)$, 'Санібель' $(1,10)$, 'Рів'єра' (1,02), 'Взірець' (1,02); ранньостиглі - 'Беллароза' $(1,16)$, Житниця (1,01); середньостиглі - 'Родинна' $(1,11)$, Ліллі $(1,04)$, Явір $(1,02)$, Княжа $(1,00)$; середньопізні - 'Случ' $(1,37)$, 'Тоскана' $(1,05)$, 'Челенджер' (1.04).

Менш адаптовані до умов зони Полісся такі сорти: надранні 'Дума' (0,84); ранньостиглі - 'Світанок київський' $(0,72)$, Паролі $(0,98)$, Опілля $(0,99)$;

середньостиглі - 'Предслава' $(0,74)$, 'Солоха' $(0,81)$, 'Констанс' (0,90), 'Гранада' (0,93), 'Есмі' $(0,99)$; середньопізні - 'Пікассо' $(0,91)$, 'Бельмонда' $(0,99)$.

Враховуючи показники середньосортової урожайності, як критерій визначення сприятливого i несприятливого для росту та розвитку картоплі комплексу встановлено, що 2020 рік є сприятливим, а 2019 несприятливим роком.

Слід зазначити, що деякі сорти картоплі на однакові умови росту та розвитку за несприятливих умов реагують специфічно. Наприклад, у 2019 році, несприятливому за погодних умов, різницю в сторону збільшення щодо середньосортового показника року показали сорти: 
'Прада' (8,1 т/га), 'Есмі' (6,5 т/га), 'Ліллі' (5,7 т/га), 'Княжа' (3,7 т/га), 'Родинна' (3,5 т/га), 'Констанс' (3,5 т/га), 'Беллароза' (3,1 т/га), 'Гранада' (3,1 т/га), 'Явір (2,1 т/га), 'Челенджер' (1,6 т/га) 'Тоскана' $(0,7$ т/га).

Це свідчить, що 11 сортам $(45,8 \%)$ від загальної кількості притаманна адаптивність, реакція на несприятливі погодні умови менш виражена, ніж у інших сортів. Особливо це стосується сорту 'Прада' $(8,1$ т/га), який має значну адаптивність сорту як за коефіцієнтом адаптивності так і за відхиленням від середньосортової урожайності.

Найвразливішими до погодних умов за роки досліджень, враховуючи сприятливий і несприятливий роки виявились сорти 3 відхиленням від середньосортової урожайності в сторону зменшення: 'Предслава' (-7,0 т/га, 2020 рік), 'Солоха' (-3,0 т/га), 'Дума' (-2,1 т/га).

Отже, реалізований потенціал продуктивності сорту 'Прада' вищий ніж сортів 'Предслава', 'Солоха', 'Дума'.

Сорти 'Прада', 'Беллароза', 'Челенджер' вирізнялися позитивною реакцією на сприятливі умови конкретного року вирощування реалізацією свого генетичного потенціалу, а саме підвищеною урожайністю, які слід віднести до сортів із специфічною адаптивністю.

Одним із важливих показників сорту є їх стійкість до стресу різниця між мінімальною та максимальною урожайністю.

Цей показник має негативний знак. Чим менше, по модулю величина показника тим вище стресостійкість сорту. Високу стійкість до стресу мають сорти 'Прада' $(-1,8)$, а також 'Предслава' $(-2,0)$, 'Челенджер' (-2,7).

Відносно стійкими можна вважати сорти 'Княжа' $(-4,4)$, Солоха ($5,3)$, Житниця $(-5,4)$, 'Гранада ' $(-5,4)$, 'Явір ' $(-5,6)$.

Щоб уникнути недоліків при встановленні абсолютного розмаху варіацій тобто абсолютного приросту між максимальним і мінімальним значенням рівнів використано модель Д. Левіса. За коефіцієнтом фенотипової стабільності (SF), як відношенням високого (Xmax) i низького (Xmin) значень встановлено, що сорти 'Прада' $(1,1)$, 'Предслава' $(1,1)$, 'Челенджер' $(1,1) \in$ високостабільними за показником врожайності; сорт 'Княжа' $(1,2)$ - середньостабільний. Усі інші сорти як $\epsilon$ низькостабільними. Проте $є$ сорти, які можна вважати відносно стабільними, тобто наближеними до значення показника 1,1, 1,2. Такими сортами є: 'Беллароза' $(1,3)$, 'Явір', 'Гранада' $(1,3)$, 'Ліллі' $(1,3)$, 'Тоскана' $(1,3)$, 'Солоха' $(1,4)$, 'Роднна' $(1,4)$, 'Бельмонда' $(1,4)$.

Критерієм високої загальної адаптивності щодо сорту є абсолютний коефіцієнт адаптивності (далі - КАА). 
За абсолютним коефіцієнтом адаптивності досліджувані сорти картоплі розмістились таким чином: надранні - 'Прада' $(1,22)$, 'Санібель' $(1,10)$, 'Взірець' $(1,04)$, 'Рів'єра ' $(1,02)$; ранньостиглі 'Беллароза' $(1,15)$, 'Житниця' $(1,01)$, 'Опілля' $(1,00)$; середньостиглі 'Родинна' $(1,10)$, 'Ліллі' $(1,02)$, 'Явір' $(1,01)$; середньопізні - 'Случ' $(1,40)$, 'Тоскана' $(1,05)$, 'Челенджер' $(1,04)$, 'Бельмонда' $(1,00)$. Усі інші сорти мали КАА менший за 1.

Зазначені сорти, що відповідали КАА 1 і вище, характеризуються високою адаптивною здатністю до агрокліматичних умов вирощування певної зони з мінливими погодними умовами в роки досліджень. Сорти з КАА менше 1 мали низьку адаптивну спроможність до критичних фаз періоду вегетації та дії на них окремих чинників навколишнього середовища.

Отже, за результатами дослідження можна зробити такі висновки.

Розраховано адаптивний потенціал, фенотипову стабільність та стійкість сортів картоплі за ознакою «урожайність». Виявлено найкращі продуктивноспроможні сорти за загальною адаптивною здатністю, стабільністю та стійкістю до стресових умов вегетаційного періоду.

Загальна адаптивна здатність 3 абсолютним коефіцієнтом адаптивності 1 i вище та відповідно величина урожайності, що перевищує багаторічну середньосортову властива сортам 'Прада' $(1,24)$, 'Санібель' $(1,10)$, 'Рів'єра' $(1,02)$, 'Взірець' $(1,02)$, 'Беллароза' $(1,16)$, Житниця $(1,01)$, 'Родинна' $(1,11)$, Ліллі $(1,04)$, Явір $(1,02)$, Княжа $(1,00)$, 'Случ' $(1,37)$, 'Тоскана' $(1,05)$, 'Челенджер' $(1.04)$.

Сорти 'Прада', 'Беллароза', 'Челенджер' вирізнялися позитивною реакцією на сприятливі умови конкретного року вирощування реалізацією свого генетичного потенціалу, а саме підвищеною урожайністю, які слід віднести до сортів із специфічною адаптивністю.

За коефіцієнтом фенотипової стабільності (SF), як відношенням високого (Xmax) і низького (Xmin) значень встановлено, що сорти 'Прада' $(1,1)$, 'Предслава' $(1,1)$, 'Челенджер' $(1,1)$ є високостабільними за показником врожайності; сорт 'Княжа' $(1,2)$ - середньостабільний. Усі інші сорти як $є$ низькостабільними.

\section{Література:}

1. Малявко А.А., Марухленко А.В., Борисова Н.П.Коэффициент адаптивности сорта картофеля определяет его продуктивность. Картофель и овощи. 2012. № 3. С. 10-11 
2. Спеціальна селекція і насінництво польових культур / за ред. В. В. Кириченка. Харків, 2010. 462 с.

3. Бондарчук А. А. Наукові основи насінництва картоплі в Україні. Біла Церква, 2010. 400 с.

4. Подгаєцький А. А., Коваленко В. М. Адаптивність сортів картоплі білоруської селекції. Вісник Сумського нац. Аграр. університету. Сер.: Агрономія і біологія. 2011. Вип. 4. С. 143-146.

URI: http://hdl.handle.net/123456789/206

5. Осипчук А. А. Стратегія селекції картоплі в умовах зміни клімату та інших факторів навколишнього середовища. Картоплярство України. 2010. № 3-4. С. 6-8.

6. Бондарчук А. А., Верменко Ю. Я., Чернохатов Л. В. Оцінка адаптивної здатності сортів картоплі за зрошення в зоні Південного Степу України. Київ : КВІЦ, 2013. 28 с.

DOI https://doi.org/10.30525/978-9934-26-111-4-55

\title{
ДОМІНУЮЧІ МІКОЗИ SORGHUM ВICOLOR В ПОЛІССІ УКРАЇНИ
}

\author{
Столяр С. Г. \\ кандидат сільськогосподарських наук, \\ старший викладач кафедри захисту рослин \\ Поліський начіональний університет \\ Ключевич М. М. \\ доктор сільськогосподарських наук, професор, \\ завідувач кафедри захисту рослин \\ Поліський національний університет \\ м. Житомир, Украӥна
}

Зміни клімату, що спостерігаються наразі мають значне відображення у розвитку агропромислового комплексу України. Асортимент продукції, що виробляється у господарствах на території українського Полісся формується за рахунок традиційних культур помірно-континентального клімату. Однак, отримати високі врожаї зернових культур в останні роки $є$ досить складно. Основними лімітуючими факторами зниження врожайності $€$ відчутні зміни 